\title{
UDP-Glucuronosyltransferase 1-9
}

National Cancer Institute

\section{Source}

National Cancer Institute. UDP-Glucuronosyltransferase 1-9. NCI Thesaurus. Code C105864.

UDP-glucuronosyltransferase 1-9 (530 aa, $\sim 60 \mathrm{kDa})$ is encoded by the human UGT 1A9 gene. This protein is involved in the metabolism of phenolic compounds. 